\title{
Protective Efficacy of Emodin against $\gamma$-Rays Induced Acute Hepatorenal Injury in Rats
}

\section{S. I. Ibrahim and S. A. Lotfi*}

Radiation Biology Dept., National Centre for Radiation Research and Technology (NCRRT), P. O. Box: 29 Nasr City, and *Biological Application Dept., Nuclear Research Centre (NRC), P. O. Box; 13759, Egypt.

D MODIN $\left(\mathrm{C}_{16} \mathrm{H}_{12} \mathrm{O}_{5}\right)$, an active principle extracted from $\mathrm{C}_{\text {Rheum palmatum. Its protective effect was evaluated against }}$ $\gamma$-rays-induced biochemical alterations in rats.

The purpose of recent study is to demonstrate protective efficacy of emodin against $\gamma$-rays induced acute hepatorenal injury in rats.

$\gamma$-irradiation (6 Gy) caused significant elevation in the release of serum alanine and aspartate transaminases, (ALT \& AST), alkaline phosphatase (SALP), lactate dehydrogenase $(\mathrm{LDH})$, bilirubin $(\mathrm{Br})$ and glucose $(\mathrm{Gu})$ with concomitant decrease in haemoglobin $(\mathrm{Hb})$ after $24 \mathrm{~h}$ of its exposure.

Toxicant exposure intensified the lipid peroxidation (LPO, measured as MDA units), total cholesterol (TC) and activity of acid phosphatase (TAC) and altered glutathione status (GSH), activities of adenosine triphosphatase (ATP), alkaline phosphatase (TALP), glutamate dehydrogenase (GDH) as well as major cellular constituents; total proteins (TP) and glycogen $(\mathrm{Gn})$ in liver and kidney, compared to control measures.

Emodin, oral treatment, significantly lessened the toxicity by protecting $\gamma$-rays-induced alterations in various blood and tissue biochemical variables, compared to irradiated groups.

Thus, the study concluded that emodin at a dose of $40 \mathrm{mg} /$ $\mathrm{kg}$ body wt possesses optimum hepatorenal protective ability in $\gamma$-irradiated toxicant rats.

Keywords: Emodin, hepatorenal distress, $\gamma$-rays, rats.

Ionizing radiation induces the production of free radicals such as hydrogen radicals, hydroxyl, singlet oxygen and peroxyl radicals, in a cascade pathway. This irradiation can lead to mortality in mammals, so it is important to protect biological systems from radiation-induced tissue damage (Rzeszowska-Wolny et al., 2009). Natural plant extracts have been shown to protect cells and tissues against ionizing radiation without adverse reactions (Tawfik and Mansour, 2008). 
Plant-derived natural products including flavonoids, terpenoids and steroids etc. have received considerable attention due to their diverse pharmacological properties (DeFeudis et al., 2003). Antioxidants play an important role in inhibiting and scavenging free radicals and provide protection against infection and degenerative diseases (Bhadauria, 2009).

Emodin is an important component of traditional Chinese herbs and has well-documented anti-inflammatory effect (Song et al., 2012). It has been shown to possess several biological activities like immuneosuppressive (Zhao et al., 2012) and as a useful chemotherapeutic agent against hepatocellular carcinoma (Jeon et al., 2012).

The present study was undertaken to investigate the possible protective effect of emodin against $\gamma$-rays-induced hepatorenal damage in rats.

\section{Materials and Methods}

\section{Animals and chemical administration}

Sprague-Dawley rats $(110 \pm 10 \mathrm{~g})$ were randomly selected from the departmental animal facility where they were inbred and housed under standard husbandry conditions $\left(25 \pm 2^{\circ} \mathrm{C}\right.$ temperature, $60-70 \%$ relative humidity and $12 \mathrm{~h}$ photoperiod). All rats were given a standard rat diet and water ad libitum. Emodin and other chemicals were purchased from Sigma-Aldrich Co., USA. Emodin was dissolved in a little amount of saturated solution of $\mathrm{NaHCO}_{3}$ and diluted with double distilled water making a dose of $40 \mathrm{mg} / \mathrm{kg} / 5 \mathrm{ml}$ and were administered orally according to Bhadauria (2009).

\section{Irradiation}

Whole-body $\gamma$-irradiation was performed at NCRRT, Cairo, Egypt, using Gamma Cell-40 biological irradiator $\left({ }^{137} \mathrm{Cs}\right)$. The dose rate was $0.46 \mathrm{~Gy} / \mathrm{min}$ at the time of the experiment.

\section{Experimental plan and samples preparations}

The rats were divided to four groups, each of 8 rats. Control group, received $5 \mathrm{ml}$ distilled water contains the same amount of saturated solution of $\mathrm{NaHCO}_{3}$ as vehicle. Emodin group, received dose of emodin ( $40 \mathrm{mg} / \mathrm{kg}$ orally). $\gamma$-irradiated group, received vehicle and submitted to a dose of 6 Gy of $\gamma$-rays. Protected group, received emodin $(40 \mathrm{mg} / \mathrm{kg}$ orally) $24 \mathrm{~h}$ before exposure to 6 
Gy of $\gamma$-rays. $24 \mathrm{~h}$ after end of the experiments, blood and liver tissues samples were harvested and immediately processed for biochemical analysis. Blood was kept for $1 \mathrm{~h}$ at room temperature after that serum was separated by centrifugation at $1000 \mathrm{~g}$ for $15 \mathrm{~min}$ and stored at $-20^{\circ} \mathrm{C}$. Liver samples were homogenized with ice-cold $150 \mathrm{mM} \mathrm{KCl}$ and $1 \%$ sucrose for the determination of MDA and GSH. Homogenates of liver was prepared in chilled hypotonic solution $(10 \% \mathrm{w} / \mathrm{v})$ for other biochemical assays

\section{Estimation of various biochemical endpoints in serum and blood}

Serum was used for the estimation of ALT \& AST (Reitman and Frankel, 1957), SALP (Roy et al., 1970), LDH (Taffs and Sitkovsky, 1991), Br (Perry et al., 1983), Hb (Swarup et al., 1992), Gu (Teitz, 1986).

\section{Liver and kidney tissue biochemical assay}

LPO measured as MDA (Ohkawa et al., 1979), GSH content (Brehe and Burch, 1976). Activities of ATP (Seth and Tangari, 1966), TAC (Barrett and Health, 1977), TALP (Roy et al., 1970), GDH (Plummer, 1989), Gn (Seifter et al., 1950), TC (Zlatkis et al., 1953).

Serum and tissue TP was measured according to Bradford (1976) method. The results are reported as means \pm S.E of 8 rats. The results were analyzed by using one way analysis of variance (ANOVA) considering significant at $P<$ 0.05 followed by student's $t$-test (Snedecor and Cochran, 1994).

\section{Results}

Emodin treated group showed non-significant changes in all blood, serum and tissues biochemical's parameters, Tables 1- 4 .

TABLE 1. Serum liver biomarker enzymes; transaminases, (ALT \& AST), alkaline phosphatase (SALP). Glucose (Gu) and lactate dehydrogenase (LDH) in different rat groups.

\begin{tabular}{|c|c|c|c|c|c|}
\hline $\begin{array}{c}\text { Rat } \\
\text { groups }\end{array}$ & $\begin{array}{c}\text { ALT } \\
(\mathrm{IU} / \mathrm{L})\end{array}$ & $\begin{array}{c}\text { AST } \\
(\mathrm{IU} / \mathrm{L})\end{array}$ & $\begin{array}{c}\text { SALP } \\
(\mathrm{IU} / \mathrm{L})\end{array}$ & $\begin{array}{c}\text { Gu } \\
(\mathrm{mg} / \mathrm{dl})\end{array}$ & $\begin{array}{c}\text { LDH } \\
(\mathrm{U} / \mathrm{L})\end{array}$ \\
\hline Control & $38.5 \pm 1.82^{\mathrm{a}}$ & $55.3 \pm 2.65^{\mathrm{a}}$ & $17.4 \pm 1.01^{\mathbf{a}}$ & $117.1 \pm 5.88^{\mathrm{a}}$ & $162.6 \pm 8.31^{\mathbf{a}}$ \\
\hline Emodin & $38.6 \pm 1.87^{\mathrm{a}}$ & $57.2 \pm 2.47^{\mathrm{a}}$ & $17.6 \pm 1.12^{\mathrm{a}}$ & $121.2 \pm 5.76^{\mathrm{a}}$ & $164.4 \pm 8.46^{\mathbf{a}}$ \\
\hline$\gamma$-rays & $82.3 \pm 4.05^{\mathbf{b}}$ & $121.5 \pm 5.43^{\mathbf{b}}$ & $28.2 \pm 1.71^{\mathbf{b}}$ & $177.4 \pm 9.65^{\mathbf{b}}$ & $321.3 \pm 16.24^{\mathbf{b}}$ \\
\hline Protected & $51.1 \pm 2.6^{\mathbf{c}}$ & $61.2 \pm 2.86^{\mathbf{c}}$ & $21.6 \pm 1.15^{\mathbf{c}}$ & $115.7 \pm 5.43^{\mathbf{c}}$ & $201.1 \pm 11.13^{\mathbf{c}}$ \\
\hline
\end{tabular}

${ }^{\mathrm{a}-\mathrm{c}}$ Means in the same column with different superscript letters differ significantly at $P<0.05$.

Egypt. J. Rad. Sci. Aplicc., Vol. 25, No. 1-2 (2012) 
Significant increases of ALT, AST, SALP, Gu and LDH activities were noticed in serum after $\gamma$-rays exposure as shown in Table 1. Emodin treatment down regulated the activities of all these enzymes towards control and exhibited 23-50\% protection, Table 1.

TABLE 2. Blood haemoglobin $(\mathrm{Hb})$ and serum bilirubin $(\mathrm{Br})$ in different rat groups.

\begin{tabular}{|c|c|c|}
\hline Rat groups & $\begin{array}{c}\text { Hb } \\
(\mathrm{g} / \mathrm{dl})\end{array}$ & $\begin{array}{c}\mathbf{B r} \\
(\mathrm{mg} / \mathrm{dl})\end{array}$ \\
\hline Control & $16.2 \pm 1.01^{\mathbf{a}}$ & $0.26 \pm 0.014^{\mathbf{a}}$ \\
\hline Emodin & $16.5 \pm 1.11^{\mathbf{a}}$ & $0.27 \pm 0.019^{\mathbf{a}}$ \\
\hline$\gamma$-rays & $12.2 \pm 1.32^{\mathbf{b}}$ & $0.43 \pm 0.021^{\mathbf{b}}$ \\
\hline Protected & $15.1 \pm 1.12^{\mathbf{c}}$ & $0.31 \pm 0.016^{\mathbf{c}}$ \\
\hline
\end{tabular}

Legends as in Table 1.

The $\gamma$-rays exposure significantly decreased blood $\mathrm{Hb}$, where as increased serum $\mathrm{Br}$ level. Emodin in protected group lessened the toxic effects of $\gamma$-rays and showed significant protection in the two blood biochemical parameters and displayed 24-28\% protection, Table 2.

TABLE 3. Tissue contents of lipid peroxidation (MDA) and glutathione (GSH) in different rat groups.

\begin{tabular}{|cl|c|c|}
\hline \multicolumn{2}{|c|}{ Rat groups } & $\begin{array}{c}\text { MDA } \\
(\text { nmole/mg protein })\end{array}$ & $\begin{array}{c}\text { GSH } \\
(\mu \mathrm{mole} / \mathrm{g} \text { tissue })\end{array}$ \\
\hline \multirow{2}{*}{ Control } & Liver & $0.56 \pm 0.043^{\mathbf{a}}$ & $8.81 \pm 0.341^{\mathbf{a}}$ \\
& kidney & $0.81 \pm 0.041^{\mathbf{a}}$ & $4.81 \pm 0.242^{\mathbf{a}}$ \\
\hline \multirow{2}{*}{ Emodin } & Liver & $0.54 \pm 0.041^{\mathbf{a}}$ & $8.83 \pm 0.343^{\mathbf{a}}$ \\
& kidney & $0.80 \pm 0.044^{\mathbf{a}}$ & $4.83 \pm 0.241^{\mathbf{a}}$ \\
\hline \multirow{2}{*}{$\gamma$-rays } & Liver & $1.26 \pm 0.66^{\mathbf{b}}$ & $4.31 \pm 0.216^{\mathbf{b}}$ \\
& kidney & $1.81 \pm 0.088^{\mathbf{b}}$ & $2.12 \pm 0.105^{\mathbf{b}}$ \\
\hline \multirow{2}{*}{ Protected } & Liver & $0.81 \pm 0.043^{\mathbf{c}}$ & $7.32 \pm 0.365^{\mathbf{c}}$ \\
& kidney & $1.22 \pm 0.064^{\mathbf{c}}$ & $4.34 \pm 0.222^{\mathbf{c}}$ \\
\hline
\end{tabular}

Legends as in Table 1.

The $\gamma$-rays exposure significantly increased liver and MDA levels, where as decreased tissues GSH levels. Emodin in protected group lessened the toxic effects of $\gamma$-rays and showed significant protection in all the tissues biochemical parameters, showing $33-105 \%$ protection, Table 3 .

Activity of TALP, ATP and GDH were diminished after $\gamma$-rays exposure in both organs, Table 4. Emodin treatment caused significant improvements in enzymatic activities of the three enzymes. $\gamma$-rays significantly increased TAC activity in liver and kidney, where as emodin dosage reduced its activity, Table 4.

Egypt. J. Rad. Sci. Aplicc., Vol. 25, No. 1-2 (2012) 
TABLE 4. Tissue enzymes activity of acid phosphatase (TAC), alkaline phosphatase (TALP), adenosine triphosphatase (ATP) and glutamate dehydrogenase (GDH) in different rat groups.

\begin{tabular}{|cl|c|c|c|c|}
\hline \multicolumn{2}{|c|}{ Rat groups } & $\begin{array}{c}\text { TAC } \\
(\mathrm{mgPi} / 100 \mathrm{ml} / \mathrm{h})\end{array}$ & $\begin{array}{c}\text { TALP } \\
(\mathrm{mgPi} / 100 \mathrm{ml} / \mathrm{h})\end{array}$ & $\begin{array}{c}\text { ATP } \\
(\mathrm{mgPi} / 100 \mathrm{ml} / \mathrm{S})\end{array}$ & $\begin{array}{c}\text { GDH } \\
(\mathrm{U} / \mathrm{g} \text { protein })\end{array}$ \\
\hline \multirow{2}{*}{ Control } & Liver & $194.4 \pm 9.9^{\mathbf{a}}$ & $53.4 \pm 2.58^{\mathbf{a}}$ & $32.3 \pm 1.57^{\mathbf{a}}$ & $2123 \pm 116.4^{\mathbf{a}}$ \\
& kidney & $224.8 \pm 11.4^{\mathbf{a}}$ & $1911.5 \pm 92.75^{\mathbf{a}}$ & $42.2 \pm 2.12^{\mathbf{a}}$ & $934 \pm 46^{\mathbf{a}}$ \\
\hline \multirow{2}{*}{ Emodin } & Liver & $197.6 \pm 9.4^{\mathbf{a}}$ & $55.6 \pm 2.46^{\mathbf{a}}$ & $32.7 \pm 1.53^{\mathbf{a}}$ & $2206 \pm 156.5^{\mathbf{a}}$ \\
& kidney & $229.2 \pm 11.7^{\mathbf{a}}$ & $1941.3 \pm 91.23^{\mathbf{a}}$ & $44.1 \pm 2.43^{\mathbf{a}}$ & $947 \pm 48^{\mathbf{a}}$ \\
\hline \multirow{2}{*}{$\boldsymbol{\gamma}$-rays } & LiveR & $292.3 \pm 15.24^{\mathbf{b}}$ & $18.1 \pm 0.87^{\mathbf{b}}$ & $15.8 \pm 0.79^{\mathbf{b}}$ & $1244 \pm 66^{\mathbf{b}}$ \\
& kidney & $281.1 \pm 14.68^{\mathbf{b}}$ & $624.4 \pm 31.19^{\mathbf{b}}$ & $20.3 \pm 1.21^{\mathbf{b}}$ & $453 \pm 23^{\mathbf{b}}$ \\
\hline \multirow{2}{*}{ Protected } & Liver & $203.4 \pm 9.87^{\mathbf{c}}$ & $27.9 \pm 1.54^{\mathbf{c}}$ & $26.1 \pm 1.46^{\mathbf{c}}$ & $1813 \pm 93^{\mathbf{c}}$ \\
& kidney & $235.1 \pm 11.18^{\mathbf{c}}$ & $1073.1 \pm 55.46^{\mathbf{c}}$ & $34.4 \pm 1.87^{\mathbf{c}}$ & $764 \pm 39^{\mathbf{c}}$ \\
\hline
\end{tabular}

Legends as in Table 1.

The $\gamma$-rays exposure significantly decreased TP contents in liver and kidney as well as hepatorenal glycogen contents, Table 5. Emodin therapy did not show protective effect on renal proteins, where as it enhanced hepatic proteins significantly. Emodin significantly reversed hepatic and renal glycogen towards control. The $\gamma$-rays exposure increased TC contents in liver and kidney. Treatment of emodin reduced TC contents significantly in both of liver and kidney, respectively, Table 5 .

TABLE 5. Tissue constituents; total protein (TP), glycogen (Gn) and total cholesterol (TC) levels in different rat groups.

\begin{tabular}{|cl|c|c|c|}
\hline \multicolumn{2}{|c|}{ Rat groups } & $\begin{array}{c}\text { TP } \\
(\mathrm{mg} / 100 \mathrm{mg})\end{array}$ & $\begin{array}{c}\text { Gn } \\
(\mathrm{mg} / 100 \mathrm{mg}))\end{array}$ & $\begin{array}{c}\text { TC } \\
(\mathrm{mg} / 100 \mathrm{~g})\end{array}$ \\
\hline \multirow{2}{*}{ Control } & Liver & $19.3 \pm 0.92^{\mathbf{a}}$ & $2591 \pm 129.6^{\mathbf{a}}$ & $2.9 \pm 0.17^{\mathbf{a}}$ \\
& kidney & $17.9 \pm 0.86^{\mathbf{a}}$ & $78 \pm 3.9^{\mathbf{a}}$ & $1.5 \pm 0.08^{\mathbf{a}}$ \\
\hline \multirow{2}{*}{ Emodin } & Liver & $19.5 \pm 0.76^{\mathbf{a}}$ & $2598 \pm 116.6^{\mathbf{a}}$ & $3.0 \pm 0.14^{\mathbf{a}}$ \\
& kidney & $18.1 \pm 0.79^{\mathbf{a}}$ & $82 \pm 3.7^{\mathbf{a}}$ & $1.6 \pm 0.07^{\mathbf{a}}$ \\
\hline \multirow{2}{*}{$\boldsymbol{\gamma}$-rays } & Liver & $14.6 \pm 0.68^{\mathbf{b}}$ & $1564 \pm 78.3^{\mathbf{b}}$ & $4.2 \pm 0.21^{\mathbf{b}}$ \\
& kidney & $14.3 \pm 0.66^{\mathbf{b}}$ & $51 \pm 3.5^{\mathbf{b}}$ & $3.0 \pm 0.16^{\mathbf{b}}$ \\
\hline \multirow{2}{*}{ Protected } & Liver & $17.7 \pm 0.86^{\mathbf{c}}$ & $2218 \pm 109.3^{\mathbf{c}}$ & $3.3 \pm 0.17^{\mathbf{c}}$ \\
& kidney & $16.3 \pm 0.83^{\mathbf{b}}$ & $73 \pm 2.7^{\mathbf{c}}$ & $2.0 \pm 0.10^{\mathbf{c}}$ \\
\hline
\end{tabular}

Legends as in Table 1.

\section{Discussion}

In the present study $\gamma$-rays-induced hepatorenal injury was evidenced by biochemical measurements. Increased level of serum ALT, AST, SALP, Gu and 
LDH indicated deterioration in the hepatic functions due to damaging effects of $\gamma$-rays. Increase in MDA accompanied by reduction in GSH implicated hepatorenal oxidative damage. Emodin intake helped in mitigating $\gamma$-raysinduced toxic consequences on liver and kidney. Since, involvement of free radicals in the pathogenesis of $\gamma$-rays-induced hepatotoxic effects is well-known (Ping et al., 2012), thus; free radical scavenging property of emodin has also been well-supported.

The $\gamma$-rays-induced depletion of cytosolic and mitochondrial GSH content lead to the loss of cellular homeostasis leading to liver injury (Limon-Pacheco and Gonsebatt, 2009). The $\gamma$-rays-induced depletion of GSH was restored towards control by emodin treatment, which is in agreement with the fact that exogenous administration of antioxidants also influences the GSH metabolism. Therefore, emodin might play a key role in protection against $\gamma$-rays intoxication by modulating the cellular GSH pool. The MDA is a good indicator of the degree of LPO (Adaramoye et al., 2012), which is closely related to $\gamma$-rays-induced tissue damage. $\gamma$-rays exposure induced LPO and subsequent hepatorenal injury supports the findings of previous study (El-Khafif et al., 2003).

In this study, $\gamma$-rays-induced cellular alterations were supposed on the basis of significant elevation in release of AST and ALT (Omran et al., 2009). Prolonged destruction in hepatic cells results in more hepatic releases to exacerbate hepatic dysfunction and causes an elevation of SALP, LDH and $\mathrm{Br}$ in serum (Schmidt, 1978). Elevation in these parameters due to $\gamma$-rays challenge is well-reported with protective effects of stem Extract of Eucalyptus maculata on them (Mohamed et al., 2005). Alteration of liver function tests after administration of emodin signifies its strong hepatoprotective activity.

Hematopoietic stem cells are highly sensitive to ionising-radiation. Hematopoietic dysfunction is the most common clinical complications of radiation exposures (Chen et al., 2007). Radiation-induced destruction of the hematopoietic systems causes depletion of peripheral blood elements, leading to a loss of function. Subsequently, the exposed individuals become susceptible to opportunistic pathogens (Walsh et al., 2009). In addition, emodin repairs damaged DNA in $\gamma$-irradiated rats indicates that it protects cells against 
radiation-induced damage which may be attributed to its ROS scavenging activity (Heo et al., 2010). These functions of emodin are likely to be factors in the protective efficacy of the irradiated rats.

Radiation induced damages to membranes of the sub cellular organelles marker enzymes; TAC, TALP and GDH could be attributed to peroxidation of membrane lipid portion monitored by the increases in MDA (Azab, 2007). In addition, hepatic injury elicits intracellular stress that leads to peroxidation of membrane lipids accompanied by alteration in the structural and the functional characteristic of the membrane, which affects the activities of the membranebound ATP (Devi et al., 2004).

In the present study, decreased activities of ATP, TALP and GDH might be due to the membrane fragility and/or altered permeability, whereas increased activity of TAC might be due to lysosomal injury. Emodin maintained the activity of these metabolic enzymes towards control either by preventing peroxidation of membrane or by stabilizing permeability or by both (Bhadauria, 2010).

Impairments in cellular metabolism due to initiation of LPO altered major cellular components ie., TP, Gn and TC. The main source of energy in liver is $\mathrm{Gn}$ and it is utilized to maintain blood Gu level (Gustavsson et al., 2010). Exposure to $\gamma$-rays increases $\mathrm{Gu}$ release and glycolysis from endogenous $\mathrm{Gn}$ (glycogenolysis) and inhibits oxygen uptake (Kang et al., 2010 and Verspohl et al., 2003). Hepatorenal Gn was reduced markedly after exposure to $\gamma$-rays in this study. Emodin therapy significantly prevented the alterations of $\mathrm{Gn}$ in liver and kidney, which was an indication of improved metabolic functioning. Emodin maintained Gn status probably by its antifibrotic mechanism because fibrosis disrupts the normal architecture and blood flow into the liver, therefore, inhibits the nutrients to be absorbed by the hepatocytes (Chavez et al., 2008).

Diminishment in hepatorenal TP and Gn contents indicated the alterations in their synthesis, whereas increase in TC might be due to the defect in the lipid metabolism and its decreased utilization by cells in toxic conditions (Baker et al., 2009 and Seyama, 2003). Emodin treatment prevented $\gamma$-rays-induced biochemical alterations in the cell components towards normal by improving

Egypt. J. Rad. Sci. Aplicc., Vol. 25, No. 1-2 (2012) 
the cellular metabolism and by providing protection against tissue necrosis (Bhadauria, 2010).

\section{Conclusion}

Emodin has the ability to regulate $\gamma$-rays-induced alterations in liver function tests, metabolic enzymatic activities, GSH and major cellular components as well as in mitigating hepatorenal cellular damage by diminishing oxidative stress.

\section{Recommendations}

Emodin needs an attention to be considered as a potential agent in limiting $\gamma$-rays-induced toxic effects.

\section{References}

Adaramoye, O. A., Adewumi, O. M., Adesanoye, O. A., Faokunla, O. O. and Farombi, E. O. (2012) Effect of tenofovir, an antiretroviral drug, on hepatic and renal functional indices of Wistar rats: protective role of vitamin E. J. Basic. Clin. Physiol. Pharmacol., 23, 69.

Azab, Kh. Sh. (2007) Modulation of Radiation Injuries in Rats Receiving Multiple Doses of Aloe Vera. Egypt. J. Rad. Sci. Applic., 20, 17.

Baker, J. E., Fish, B. L., Su, J., Haworth, S. T., Strande, J. L., Komorowski, R. A., Migrino, R. Q., Doppalapudi, A., Harmann, L., Allen, L. i. X., Hopewell, J. W., Moulder, J. E. (2009) 10 Gy total body irradiation increases risk of coronary sclerosis, degeneration of heart structure and function in a rat model. Int. J. Radiat. Biol., 85, 1089.

Barrett, A. J. and Health, M. F. (1977) Lysosomal enzymes. In: Lysosomes: A Laboratory Handbook, $2^{\text {nd }}$ ed. (Ed. J.T.Dingle), Elsevier/ Noeth-Holland Biomedical Press, Amesterdam. p. 19.

Bhadauria, M. (2010) Dose-dependent hepatoprotective effect of emodin against acetaminophen-induced acute damage in rats. Experim. Toxicol. Pathol., 62, 627.

Bradford, M. M. (1976) A rapid and sensitive method for the quantitation of microgram quantities of protein utilizing the principle of protein-dye binding. Anal. Biochem., 72, 248.

Brehe, J. and Burch, H. (1976) Enzymatic assay for glutathione. Anal. Biochem., 74, 189.

Chavez, E., Reyes-Gordillo, K., Segovia, J., Shibayama, M., Tsutsumi, V., Vergara, P., Moreno, M. G. and Muriel, P. (2008) Resveratrol prevents fibrosis, NF$\mathrm{k} \mathrm{B}$ activation and TGF-b increase induced by chronic CCl4 treatmentinrats. J. Appl. Toxicol., 28, 35.

Egypt. J. Rad. Sci. Aplicc., Vol. 25, No. 1-2 (2012) 
Chen, T., Burke, K. A., Zhan, Y., Wang, X., Shibata, D. and Zhao, Y. (2007) IL-2 facilitates both recovery of endogenous hematopoiesis and the engraftment of stem cells after ionizing radiation. Exp. Hematol., 35, 203.

DeFeudis, F. V., Papadopoulos, V. and Drieu, K. (2003) Ginkgo biloba extracts and cancer: a research area in its infancy. Fundam. Clin. Pharmacol., 17, 405.

Devi, K. P., Sreepriya, M., Balakrishna, K. and Devaki, T. (2004) Protective effect of Premna tomentosa (L. Verbenaceae) extract on membrane-bound phosphatases and inorganic cations transport in acetaminophen-induced hepatotoxicity rats. J. Ethnopharmacol., 93, 371.

El-Khafif, M., Ragab, M., El-Dawy, H. and Tawfik, S. (2003) Effect of taurine treatment on some biochemical parameters in gamma irradiated mice. $J$. Environ. Sci., 6, 393.

Gustavsson, C., Yassin, K., Wahlstrom, E., Cheung, L., Lindberg, J., Brismar, K., Ostenson, C. G., Norstedt, G. and Tollet-Egnell, P. (2010) Sex-different hepatic glycogen content and glucose output in rats. BMC Biochem., 11, 38.

Heo, S. K., Yun, H. J., Noh, E. K. and Park, S. D. (2010) Emodin and rhein inhibit LIGHT-induced monocytes migration by blocking of ROS production. Vascul Pharmacol., 53, 28.

Jeon, W., Jeon, Y. K. and Nam, M. J. (2012) Apoptosis by aloe-emodin is mediated through down-regulation of calpain-2 and ubiquitin-protein ligase E3A in human hepatoma Huh-7 cells. Cell Biol. Int., 36, 163.

Kang, K. A., Zhang, R., Chae, S., Lee, S., Kim, J., Kim, J., Jeong, J., Lee, J., Shin, T., Lee, N. H. and Hyun, J. W. (2010) Phloroglucinol (1,3,5trihydroxybenzene) protects against ionizing radiation-induced cell damage through inhibition of oxidative stress in vitro and in vivo. Chemico-Biolog. Interact., 185, 215.

Limon-Pacheco, J. and Gonsebatt, M. E. (2009) The role of antioxidants and antioxidant-related enzymes in protective responses to environmentally induced oxidative stress. Mutat. Res., 674, 137.

Mohamed, A. F., Hasan, A. G. A., Hamamy M. I. and Abdel-Sattar, E. (2005) Antioxidant and hepatoprotective effects of Eucalyptus maculata. Med. Sci. Monit., 11, 426.

Ohkawa, H., Ohishi, N. and Yagi, K. (1979) Assay for lipid peroxides in animal tissues bythiobarbituric acid reaction. Anal. Biochem., 95, 351.

Omran, M. F., Abouelella, A. M. K. and Shahein, Y. E. (2009) Amifostine (WR2721) drug controls radiation induced damage in rats. Egypt. J. Rad. Sci. Applic., 22, 397. 
Perry, B., Doumas, B. and Bayes, D. (1983) A candidate reference method for determination of bilirubin in serum. Test for transferability. Clin. Chem., 29, 297.

Ping, X., Junqing, J., Junfeng, J. and Enjin, J. (2012) Radioprotective effects of troxerutin against gamma irradiation in mice liver. Int. J. Radiat. Biol., 88, 607.

Plummer, D. (1989) An Introduction to Biochemistry. 3rd Edition. p. 265, Mc Graw Hill Book Company, London.

Reitman, S. and Frankel, S. (1957) A calorimetric method for determination serum transaminasis. Am. J. Clin. Path., 28, 56.

Roy, A, Brower, M. and Hayden, J. (1970) Sodium thymolphthalein monophosphate. A new acid phosphatase substrate with greater specificity for the prostate enzyme in serum. Clin. Chem., 17, 1093.

Rzeszowska-Wolny, J., Przybyszewski, W. M. and Widel, M. (2009) Ionizing radiation-induced bystander effects, potential targets for modulation of radiotherapy. Eur. J. Pharmacol., 625, 156.

Schmidt, E. (1978) Strategy and evaluation of enzyme determinations in serum in diseases of the liver and the biliary system. In: Demers LM, Shaw LM, editors. Evaluation of liver function: a multifaceted approach, Urban and Schwarzenberg: Baltimore, pp. 79-102.

Seifter, S., Dayton, S., Novic, B. and Muntwyler, E. (1950) The estimation of glycogen with the anthrone reagent. Arch. Biochem. Biophys., 50, 191.

Seth, P. K. and Tangari, K. K. (1966) Biochemical effects of newer salicylic acid congenesis. J. Pharm. Pharmacol., 18, 831.

Seyama, Y. (2003) Cholestanol metabolism, molecular pathology, and nutritional implications. J. Med. Food., 6, 217.

Snedecor, G. W. and Cochran, W. G. (1994) Statistical methods, 8th ed. Ames, Iowa: Iowa State University Press, pp. 217-236.

Song, Z. C., Wang, Z. S., Bai, J. H., Li, Z. and Hu, J. (2012) Emodin, a naturally occurring anthraquinone, ameliorates experimental autoimmune myocarditis in rats. Tohoku. J. Exp. Med., 227, 225.

Swarup, H., Arora, S. and Pathak, S. C. (1992) Laboratory techniques in modern biology. New Delhi: Kalyani Publishers, pp. 187-189.

Taffs, R. and Sitkovsky, M. (1991) In vitro assays for mouse B and T lymphocyte function. In: Current Protocols in Immunology, Coligan, J. E., Kruisbeek, A. M., Margulies, D. H., Shevach, E. M. and Strober, W., eds, Greene Publishing, Wiley Interscience, New York, pp. 1-8.

Tawfik, S. S. and Mansour, H. H. (2008) Monitoring the therapeutic and protective role of the anti oxidative nutritional factor beta carotene in gamma-irradiated rats. Egypt. J. Rad. Sci. Appl., 21, 63.

Egypt. J. Rad. Sci. Aplicc., Vol. 25, No. 1-2 (2012) 
Teitz, N. W. (1986) Textbook of clinical chemistry. WB Saunders London-Philadelphia, p. 796.

Verspohl, E. J., Blackburn, G. M., Hohmeier, N., Hagemann, J. and Lempka, M. (2003) Synthetic, nondegradable diadenosine polyphosphates and diinosine polyphosphates: their effects on insulin-secreting cells and cultured vascular smooth muscle cells. J. Med. Chem., 46, 1554.

Walsh, T. K. (2009) Advances and challenges in infectious diseases supportive care of patients with hematologic malignancies, hematopoietic stem cell transplantation and severe aplastic anemia. Semin. Hematol., 46, 191.

Zhao, L. M., Zhang, L. M., Liu, J. J., Wan, L. J., Chen, Y. Q., Zhang, S. Q., Yan, Z. W. and Jiang, J. H. (2012) Synthesis and antitumor activity of conjugates of 5-Fluorouracil and emodin. Eur. J. Med. Chem., 47, 255.

Zlatkis, A., Zak, B. and Boyle, A. J. (1953) A new method for the direct determination of serum cholesterol. J. Lab. Clin. Med., 41, 486.

(Received: 21/12/2012;

accepted: 17/02/2013) 


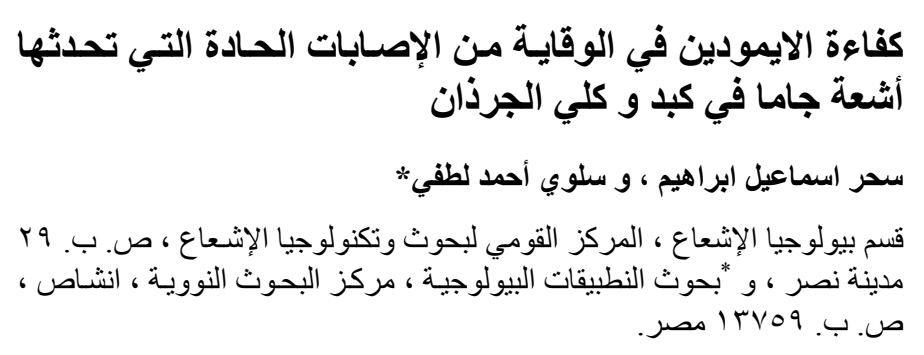

يستخرج الايمودين من جذر نبات الفنتيلاجو الهندي ، و قد تم تقيهم

دوره في حماية الجرذان من التغييرات الكيمو حيوية التي تحدثها أنثعة جاما.

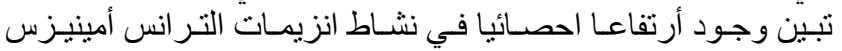

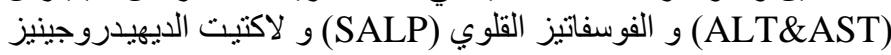

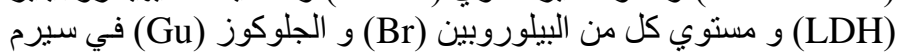

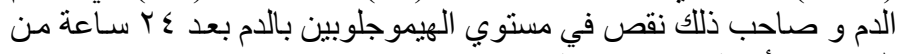

التعرض لأشعة جاما (جر عة 7 جراي).

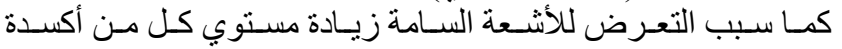

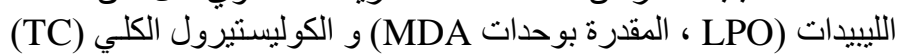

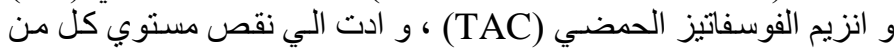

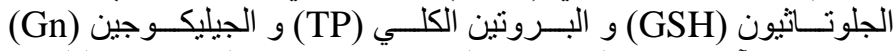

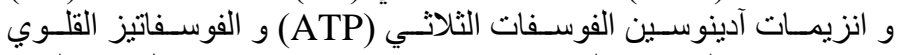

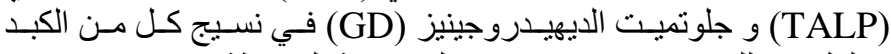

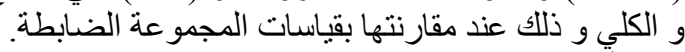

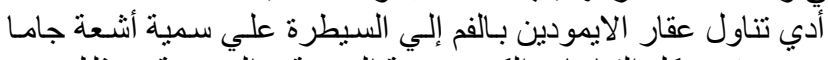

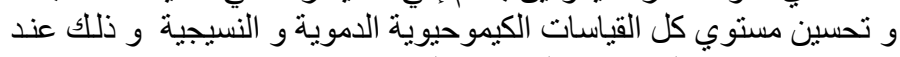

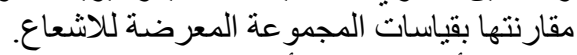

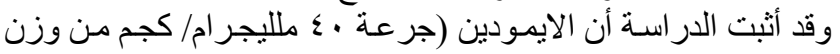

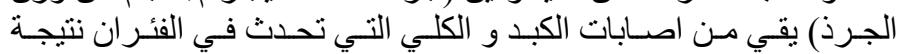

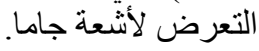

Egypt. J. Rad. Sci. Aplicc., Vol. 25, No. 1-2 (2012) 